\title{
PDGFRA Gene Fusion Positive
}

National Cancer Institute

\section{Source}

National Cancer Institute. PDGFRA Gene Fusion Positive. NCI Thesaurus. Code C148117.

An indication that a PDGFRA fusion gene has been detected in a sample. 